\title{
Zajęcie zabezpieczonych środków pieniężnych znajdujących się na rachunku depozytowym. Glosa do wyroku Sądu Apelacyjnego w Poznaniu z dnia 14 maja 2008 r. I ACa 345/08
}

\section{Wprowadzenie}

Sąd Apelacyjny w Poznaniu w wyroku z dnia 14 maja 2008 r. (I ACa 345/08) orzekł o tym, że nie ma przeszkód w przedmiocie skierowania egzekucji do środków dłużnika, które $\mathrm{w}$ innym postępowaniu zostały zabezpieczone na podstawie przepisów art. 730 i nast. kodeksu postępowania cywilnego ${ }^{2}$ oraz przekazane na rachunek depozytowy właściwego sądu (art. $752 \S 1$ zd. 2 k.p.c.) $)^{3}$. Równocześnie wskazując, że zajęcie takich środków winno nastąpić z zastosowaniem przepisów dotyczących egzekucji z ruchomości. Bez wątpienia należy zaaprobować orzeczenie Sądu Apelacyjnego w Poznaniu w zakresie możliwości prowadzenia egzekucji z zabezpieczonych na rachunku depozytowym środków, pod wątpliwość jednak poddając wskazany przez sąd sposób ich egzekucji, tj. egzekucji z ruchomości. Słuszny wydawać się może pogląd, odmienny od wskazanego przez sąd, że właściwym sposobem egzekucji w tego typu przypadkach będzie egzekucja z innych praw majątkowych.

W dalszej części orzeczenia sąd wskazał, że przy podziale zajętej kwoty wierzyciel, który uzyskał zabezpieczenie (z wyjątkami przewidzianymi w ustawie, takimi jak hipoteka, zastaw rejestrowy), nie znajduje się w uprzywilejowanej

1 Mgr Stanisław Nowak - prawnik, doktorant na Wydziale Prawa Administracji Uniwersytetu Jagiellońskiego, asesor komorniczy przy Sądzie Rejonowym dla Krakowa-Krowodrzy (e-mail: stanislawnowak@ya.ru).

2 Dalej jako „k.p.c.”, tj.: Dz.U. z 2014 r., poz. 101 ze zm.

3 Stanowisko sądu pozostaje aktualne po wejściu w życie w styczniu 2015 r. nowelizacji k.p.c. (Dz.U. z 2014 r., poz. 1626), którą zastąpiono rachunek depozy towy sądu rachunkiem depozytowym Ministra Finansów. 
pozycji w stosunku do innych wierzycieli, co wynika wprost z kolejności zaspokajania wymienionej w art. 1025 k.p.c. ${ }^{4}$.

Należy nadmienić, że wyrok ten dotyczy de facto kolizji postępowania zabezpieczającego i egzekucyjnego, przy czym, jak wskazuje Zbigniew Szczurek: „przepisy prawa egzekucyjnego nie regulują zbiegu egzekucji sądowej z zabezpieczeniem (...). Do tych zbiegów mają zastosowanie ogólne zasady prawa egzekucyjnego, według których zabezpieczenie konserwacyjne, ograniczające się zwłaszcza do egzekucyjnego zajęcia określonego składnika majątku dłużnika, nie stanowi żadnej przeszkody w prowadzeniu egzekucji z tego samego składnika przez innego wierzyciela" ${ }^{5}$. Inaczej ma się rzecz, jeżeli mamy do czynienia z zabezpieczeniem nowacyjnym. Jeżeli bowiem postanowienie o udzieleniu zabezpieczenia podlega wykonaniu w drodze egzekucji, do wykonania tego postanowienia stosuje się odpowiednio przepisy o postępowaniu egzekucyjnym ${ }^{6}$.

Niemniej jednak w przedmiotowym stanie faktycznym nie mamy do czynienia ze zbiegiem obydwu postępowań, gdyż postępowanie zabezpieczające zostało już de facto zakończone poprzez zabezpieczenie kwoty na rachunku depozytowym sądu, do którego w dalszej kolejności zostało skierowane zajęcie.

\section{Stan faktyczny}

W toczącym się postępowaniu sąd rejonowy dnia 9 sierpnia 2005 roku wydał nakaz zapłaty, w którym orzekł, że pozwany $X$ ma zapłacić na rzecz powoda $Y$ łączną kwotę 105 807,65 zł. Po czym z wniosku uprawnionego Y komornik wszczął postępowanie zabezpieczające na podstawie ww. nakazu zapłaty, w ramach którego zajął rachunek bankowy obowiązanego X, zabezpieczył kwotę 105 807,65 zł i przekazał ją na rachunek depozytowy sądu rejonowego.

Następnie do komornika wpłynęły wnioski o wszczęcie egzekucji przeciwko $\mathrm{X}$, wobec czego zostało dokonane zajęcie wierzytelności o wypłatę kwoty zabezpieczenia znajdującego się na rachunku depozytowym sądu na poczet toczących się postępowań egzekucyjnych - finalnie kwota ta została przelana na rachunek bankowy komornika i dnia 15 listopada 2005 roku podzielona między wierzycieli

\footnotetext{
$4 \quad$ Z. Woźniak, [w:] J. Gołaczyński (red.), Wybrane zagadnienia egzekucji sq̨dowej, Warszawa 2008, s. 58-360.

$5 \quad$ Z. Szczurek, [w:] Z. Szczurek (red.), Kodeks postępowania cywilnego. Postępowanie zabezpieczające i egzekucyjne. Komentarz, Sopot 2013, s. 203.

6 M. Muliński, [w:] J. Jankowski (red.), Kodeks postępowania cywilnego. Postępowanie egzekucyjne. Komentarz do artykułów 758-1088, Warszawa 2011, s. 5-6.
}

$7 \quad$ Z. Woźniak, op. cit., s. 340-342. 
Wobec ogłoszenia upadłości dłużnika syndyk masy upadłości X wniósł o zasądzenie na jego rzecz od pozwanych solidarnie: komornika, Skarbu Państwa oraz wierzyciela Y wyegzekwowanej kwoty tj. 105 807,65 zł. Sąd Okręgowy w Poznaniu, Wydział I Cywilny wyrokiem z dnia 20 lutego 2008 r. oddalił powództwo w całości, wskazując, że wierzytelność (suma pieniędzy zabezpieczona dla danego postępowania) może być zajęta przez komornika sądowego i rozdysponowana między inne postępowania. Sąd równocześnie zwrócił uwagę na fakt, że w sytuacji naruszenia art. 146 ust. 2 prawa upadłościowego i naprawczego ${ }^{8}$ (wydanie dochodzonej kwoty nastąpiło po dacie wydania postanowienia o ogłoszeniu upadłości), prawidłową podstawą prawną żądania zwrotu wydanych sum od wierzyciela stanowi art. 405 kodeksu cywilnego ${ }^{9}$ nie zaś wskazywany przez powoda - syndyka art. $410 \S 2$ k.c., bowiem od dnia ogłoszenia upadłości dłużnika można dochodzić należnej kwoty jedynie przez udział w postępowaniu upadłościowym.

Apelację od powyższego wyroku wniósł powód - syndyk, zaskarżając go w całości, zarzucając rozstrzygnięciu naruszenie prawa materialnego poprzez jego błędną wykładnię i niewłaściwe zastosowanie przez przyjęcie, że pozwany - komornik - miał prawo zająć kwoty znajdujące się w depozycie sądowym i rozdysponować je do innych postępowań egzekucyjnych.

\section{Analiza rozstrzygnięcia Sądu}

Przechodząc do analizy rozstrzygnięcia sądu, należy rozpocząć od jego stanowiska w kwestii oceny czynności komornika polegających na skierowaniu egzekucji do środków pieniężnych zgromadzonych na depozycie sądowym, a zabezpieczonych na podstawie nieprawomocnego nakazu zapłaty.

Sąd wskazał, że zajęcie wierzytelności z rachunku bankowego obowiązanego $\mathrm{w}$ wyniku udzielenia wierzycielowi zabezpieczenia jego roszczenia pieniężnego na podstawie przepisów art. 730 i nast. k.p.c. oraz przekazanie uzyskanych w ten sposób środków na rachunek depozytowy sądu (art. $752 \S 1$ zd. 2 k.p.c.) nie oznacza, że środki te przestają stanowić składnik majątku dłużnika (por. art. $752 \S 2$ zd. 2 k.p.c.). Mogą być one zatem przedmiotem egzekucji prowadzonej w trybie przewidzianym dla egzekucji z ruchomości.

Nie prowadzi to do naruszenia jakichkolwiek praw uprawnionego, na rzecz którego dokonano zabezpieczenia. Uczestniczy on bowiem w podziale sum uzy-

\footnotetext{
8 Ustawa z dnia 28 lutego 2003 r. - Prawo upadłościowe i naprawcze, Dz.U. z 2015 r., poz. 233 ze zm.

9 Dalej jako „k.c.”, tj.: Dz.U. z 2014 r., poz. 121 ze zm.
} 
skanych z egzekucji na zasadach przewidzianych dla wierzycieli niedysponujących jeszcze tytułami wykonawczymi (por. art. 1030 k.p.c., art. 1032 k.p.c.) ${ }^{10}$.

Odnosząc się do samego sposobu zajęcia zabezpieczonych środków, sąd wskazał, że egzekucja ta nie mogła nastąpić w drodze zajęcia wierzytelności, gdyż w ten sposób mogłoby dojść co najwyżej do zajęcia wierzytelności przyszłej, jeszcze niewymagalnej, co do której wierzyciel mógł jedynie wykonywać uprawnienia, o których mowa w art. 887 § 1 k.p.c. w zw. z art. 902 k.p.c. Wierzytelność ta stałaby się wymagalna dopiero po prawomocnym zakończeniu postępowania, w którym dokonano zabezpieczenia (art. $744 \S 1$ k.p.c., art. $754^{1} \S 2$ k.p.c.). Uznał, że zajęcie to należy potraktować jako egzekucję z ruchomości.

Wydaje się oczywiste, że pieniądze znajdujące się na rachunku depozytowym nie są inną wierzytelnością, bowiem nie zachodzi tu typowa „konstrukcja wierzytelności, stanowiąca podstawową instytucję prawa zobowiązań, traktowana (...) jako skupiająca wszystkie uprawnienia wierzyciela wynikające z określonego stosunku zobowiązaniowego. Wierzytelność jest nierozłącznie związana z długiem. Jak wskazuje się w doktrynie, wierzytelność i dług są dwiema stronami tego samego stosunku prawnego (zobowiązania), które są dostrzegalne w zależności od postrzegania tego stosunku od strony uprawnionej czy zobowiązanej. Wierzytelność jest prawem podmiotowym względnym skierowanym tylko do dłużnika. Jest to cecha odróżniająca ją od praw rzeczowych skutecznych przeciwko każdej osobie. W ramach struktury stosunku zobowiązaniowego można wskazać na świadczenia mające charakter trwały (np. dożywotnie użytkowanie), jednorazowy (np. sprzedaż, zamiana) bądź okresowy (np. najem, praca). Obok świadczeń okresowych przedmiotem zobowiązań trwałych mogą być również świadczenia ciągłe. Polegają one na określonym stałym zachowaniu się dłużnika przez cały czas trwania stosunku prawnego (np. świadczenie wynajmującego, wydzierżawiającego, przechowawcy)"11.

W ramach zajęcia wierzytelności osoba, która ma spełnić świadczenie, czyni je na rzecz komornika. W omawianym przypadku zachodzi więc relacja na linii sąd (wierzyciel) - bank (dłużnik). Bank jest bowiem zobowiązany świadczyć na rzecz sądu ze względu na to, że otworzył dla sądu rachunek depozytowy.

Sąd w orzeczeniu wskazuje, że właściwym sposobem egzekucji w takim przypadku jest zastosowanie przepisów dotyczących egzekucji z ruchomości. Nie mogę się zgodzić z tą tezą. Jednocześnie odrzucając możliwość egzekwowania tych środków jako wierzytelności oraz ruchomości, stoję na stanowisku, że właściwe zastosowanie znajdują tu przepisy dotyczące egzekucji z innych praw majątkowych.

\footnotetext{
10 A. Marciniak, Sądowe postępowanie egzekucyjne, Warszawa 2011, s. 413-421.

11 T. Żyznowski, [w:] H. Dolecki, T. Wiśniewski (red.), Kodeks postępowania cywilnego. Komentarz Lex, t. IV, Warszawa 2014, s. 468-469.
} 
Na poparcie mojej tezy chciałbym przywołać definicję ruchomości - są nimi wszystkie rzeczy, które nie są nieruchomościami, ani ich częściami składowymi. Rzeczami ${ }^{12} \mathrm{w}$ rozumieniu prawa cywilnego są zaś materialne części przyrody w stanie pierwotnym lub przetworzonym, na tyle wyodrębnione w sposób naturalny lub sztuczny, że w stosunkach społeczno-gospodarczych mogą być traktowane jako dobra samoistne ${ }^{13}$. Taka konstrukcja może być stosowana w sytuacji, gdy mamy do czynienia z konkretnymi banknotami (materialnymi), natomiast w momencie, gdy pieniądze trafiły na rachunek depozytowy, krążą w systemie bankowym. Mając to na uwadze, należy wskazać, że wpłacający w momencie wypłaty środków otrzyma taką samą kwotę, a nie te same banknoty.

Odnosząc się do innych praw majątkowych, warto by zacytować Magdalenę Rośniak-Marczuk, która podnosi, że przedmiotem egzekucji z innych praw majątkowych są „zbywalne prawa majątkowe inne niż wierzytelności. Prawami majątkowymi w tym rozumieniu są wszelkie prawa podmiotowe, z których wynika obowiązek świadczeń majątkowych, a więc nie tylko pieniędzy, lecz także rzeczy oznaczonych co do gatunku lub co do tożsamości" ${ }^{14}$. Środki pieniężne, które trafiły na rachunek depozytowy stanowią w dalszym ciągu własność dłużnika (obowiązanego) i stanowią jego prawa majątkowe. Należy w tym miejscu zgodzić się z orzeczeniem sądu, że egzekucja ta mogła dojść do skutku, jednakże z zastrzeżeniem, że powinno się używać odpowiedniej terminologii ${ }^{15}$. Rozróżnienie to natomiast z punktu widzenia proceduralnego może powodować pewne problemy m.in. ze względu na fakt, że „mimo wyodrębnienia przepisów o egzekucji z innych praw majątkowych z obowiązującego przed 2.07.2004 r. działu IV tytułu II części III k.p.c., nadal można wskazać pewien stopień powiązania wspomnianego sposobu egzekucji z egzekucją z innych wierzytelności. Co więcej wydaje się, że wspomniane wyodrębnienie nie do końca zostało przeprowadzone w sposób konsekwentny. O istniejącym powiązaniu przepisów działu IVa z przepisami działu IV tytułu II części III k.p.c. świadczy brzmienie art. 909 k.p.c., zgodnie z którym w egzekucji z innych praw majątkowych należy stosować odpowiednio przepisy o egzekucji z innych wierzytelności, chyba że przepisy wspomnianego działu IVa stanowią inaczej"16. $^{\prime 16}$.

\footnotetext{
12 Zgodnie z art. 45 k.c. rzeczami są wyłącznie przedmioty materialne.

13 S. Cieślak, [w:] J. Jankowski (red.), Kodeks postępowania cywilnego..., op. cit., s. 519.

14 M. Rośniak-Marczuk, [w:] J. Jankowski (red.), Kodeks postępowania cywilnego..., op. cit., s. 693.

15 A. Marciniak, op. cit., s. 413-421.

16 M. Rośniak-Marczuk, op. cit., s. 691.
} 


\section{Podsumowanie}

Na zakończenie rozważań chciałbym podkreślić, że wystąpienie nieprawidłowości proceduralnych (a dokładniej rzecz ujmując terminologicznych), których dopuścił się komornik, nie stanowiło na tyle poważnego naruszenia procedury, żeby mogło zostać uwzględnione, co w konsekwencji skutkowało oddaleniem apelacji. Zdaniem sądu środki pieniężne, które zostały w jednym postępowaniu zabezpieczone, w dalszym ciągu stanowiły składnik majątku dłużnika (obowiązanego), dlatego mimo zastosowania nieprawidłowego środka egzekucja ta była zasadna. Nie doszło też do pokrzywdzenia innych wierzycieli.

Istotną konkluzją wynikającą z analizy glosowanego orzeczenia jest stwierdzenie:

\środki pieniężne znajdujące się na rachunku depozytowym sądu podlegają egzekucji jako składnik majątku dłużnika,

uchybienie zaistniałe $w$ związku z zastosowaniem niewłaściwego środka egzekucyjnego nie powoduje nieważności postępowania egzekucyjnego.

Reasumując, przy zajęciu takich środków bez większej różnicy pozostaje, czy zostanie ono dokonane $\mathrm{w}$ trybie wskazanym przez sąd - poprzez zastosowanie przepisów dotyczących egzekucji z ruchomości, czy też zajęcie innych praw majątkowych. Oceniając czynności podejmowane w trakcie postępowania egzekucyjnego, należy pamiętać przede wszystkim, że stosownie do art. 2 ustawy z dnia 29 sierpnia 1997 r. o komornikach sądowych i egzekucji ${ }^{17}$ komornik powinien działać szybko, sprawnie i rzetelnie, gdyż podstawowym zadaniem postępowania egzekucyjnego jest zaspokojenie roszczenia wierzyciela.

\section{Bibliografia}

Dolecki H., Wiśniewski T. (red.), Kodeks postępowania cywilnego. Komentarz Lex, t. IV, Warszawa 2014.

Gołaczyński J. (red.), Wybrane zagadnienia egzekucji sądowej, Warszawa 2008.

Jankowski J. (red.), Kodeks postępowania cywilnego. Postępowanie egzekucyjne. Komentarz do artykułów 758-1088, Warszawa 2013.

Marciniak A., Sądowe postępowanie egzekucyjne, Warszawa 2011.

SA w Poznaniu w wyroku z dnia 14.05.2008 r., I ACa 345/08, dostępny w Systemie Informacji Prawnej Lex nr 446165.

Szczurek Z. (red.), Kodeks postępowania cywilnego. Postępowanie zabezpieczające i egzekucyjne. Komentarz, Sopot 2013.

17 Tj. Dz.U. z 2015 r., poz. 790 ze zm. 